\title{
The Chasteen Site (41UR18) on Big Cypress Creek, Upshur County, Texas
}

Timothy K. Perttula

Heritage Research Center, Stephen F. Austin State University

Follow this and additional works at: https://scholarworks.sfasu.edu/ita

Part of the American Material Culture Commons, Archaeological Anthropology Commons, Environmental Studies Commons, Other American Studies Commons, Other Arts and Humanities Commons, Other History of Art, Architecture, and Archaeology Commons, and the United States History Commons

Tell us how this article helped you.

This Article is brought to you for free and open access by the Center for Regional Heritage Research at SFA ScholarWorks. It has been accepted for inclusion in Index of Texas Archaeology: Open Access Gray Literature from the Lone Star State by an authorized editor of SFA ScholarWorks. For more information, please contact cdsscholarworks@sfasu.edu. 


\section{The Chasteen Site (41UR18) on Big Cypress Creek, Upshur County, Texas}

Creative Commons License

(c) (i) (8)

This work is licensed under a Creative Commons Attribution-NonCommercial 4.0 International License 


\title{
The Chasteen Site (41UR18) on Big Cypress Creek, Upshur County, Texas
}

\author{
Timothy K. Perttula
}

\section{INTRODUCTION}

The Chasteen site (41UR18), also known as the W. S. Chastain site (Thurmond 1990:212 and Figure 27) appears to be an early Titus phase (ca. A.D. 1450-1550) mound center and village (with an associated cemetery) on an upland landform overlooking Big Cypress Creek. The small mound (18 $\mathrm{m}$ in diameter and $1.5 \mathrm{~m}$ in height) at the Chasteen site, apparently constructed over an important building, is part of a larger complex of Titus phase mound centers at this locale, including the Harroun (4IUR 10), Camp Joy (41UR I44), and the Dalton (4IUR11) sites (Perttula 2012:Figure 13-2).

The village deposits at the Chasteen site are estimated to cover 3-4 acres around the mound, and contain numerous ceramic sherds and concentrations of daub from ancestral Caddo house structures contemporaneous with the house mound (Thurmond 1990:212). Other artifacts in the village indicate some very limited use of the upland in Late Archaic and Early Caddo periods. The Robert L. Turner, Jr. surface collection from the site came from a midden area within the village.

\section{LITHIC ARTIFACTS}

Only one lithic artifact is in the surface collection from the Chasteen site. This is a multi-platform flake core on a heat-treated quartzite.

\section{CERAMIC ARTIFACTS}

There are 61 ceramic sherds in the Turner surface collection from the Chasteen site, including 33 plain rim and body sherds and 28 decorated sherds. The plain to decorated sherd ratio is 1.18 . As with many Late Caddo Titus phase ceramic assemblages, the vast majority of the sherds in the surface collection are from grog-tempered vessels $(98 \%)$; the one remaining sherd is bone-tempered.

Ten of the decorated sherds $(36 \%)$ are from engraved or red-slipped fine ware vessels, primarily carinated bowls. The redslipped body sherd has a slip only on the exterior vessel surface. The carinated bowl and compound bowl sherds have horizontal engraved lines with open and hatched pendant triangles on them (Figure 1a-c). These are likely from Ripley Engraved vessels.

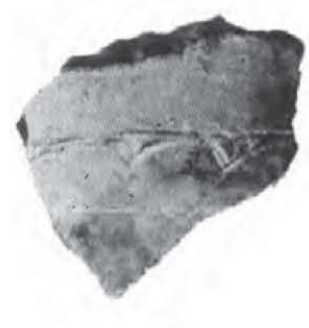

a
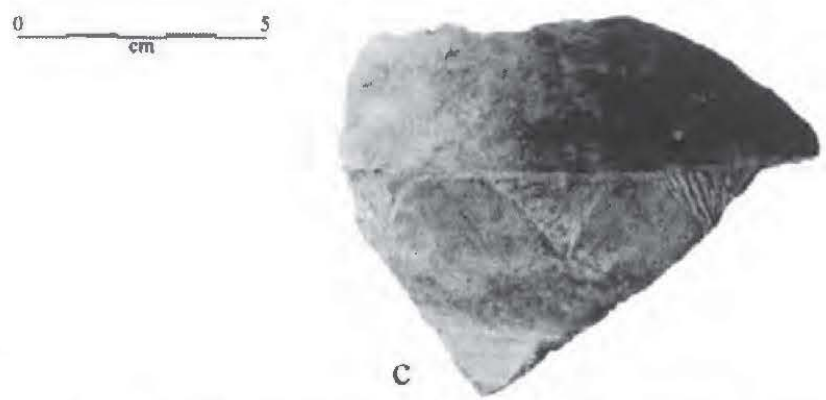

Figure 1. Engraved compound bowl and carinated bowl sherds: a, compound bowl; b-c, carinated bowl sherds. 
Other engraved rim sherds have horizontal engraved lines under the lip $(n=2)$ (direct profiles and rounded, exterior folded lips). Two body sherds have hatched triangle and hatched divider elements from different Ripley Engraved vessels.

The two bottle body sherd have either curvilinear engraved lines or curvilinear engraved lines with open and hatched spurs and triangular elements (Figure 2a). This sherd is likely from a Ripley Engraved bottle.

The 18 decorated sherds from utility ware vessels are from tool punctated $(10.7 \%$ of the

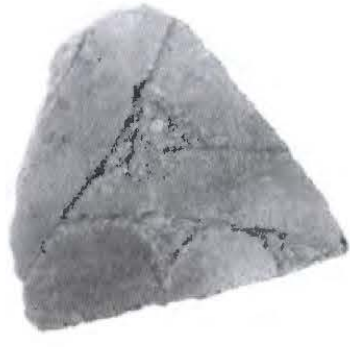

a

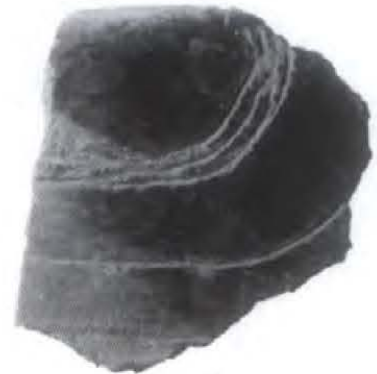

b

$\underline{0}$ 5

Figure 2. Engraved bottle and carinated bowl sherds. decorated sherds and $16.7 \%$ of the utility ware sherds) (Figure 3a, e), incised (3.6\% of the decorated sherds and $5.6 \%$ of the utility ware sherds) (Figure $4 \mathrm{~b}$ ), neck banded (La Rue Neck Banded, $3.6 \%$ of the decorated sherds and $5.6 \%$ of the utility ware sherds) (Figure 3d), and appliqued-incised (3.6\% of the decorated sherds and $5.6 \%$ of the utility ware sherds) vessels (Figure 3c). The appliqued-incised body sherd is likely from a Harleton Appliqued jar, while the incised sherd is a rim (everted profile and a rounded lip) with closely-spaced horizontal lines.

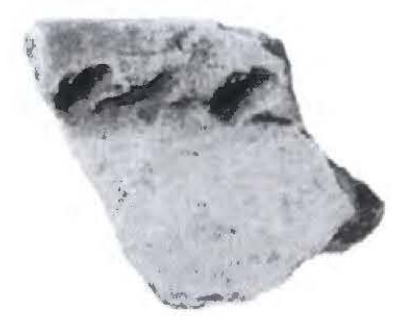

a

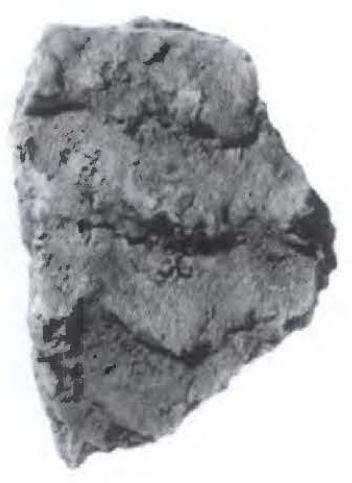

d

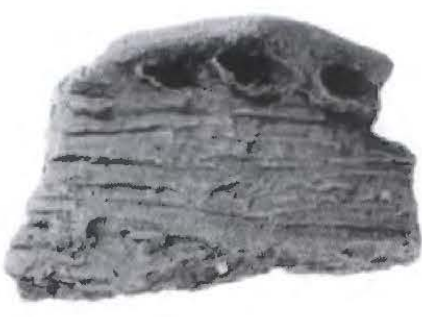

b

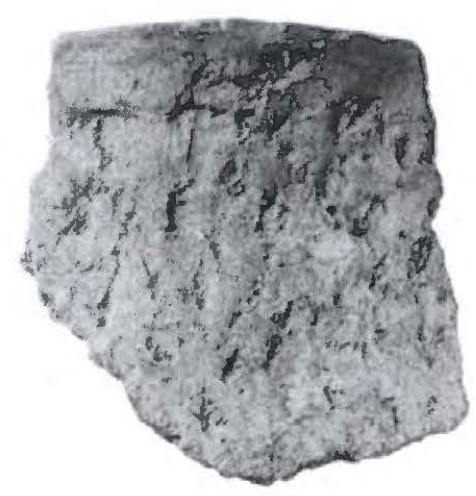

e

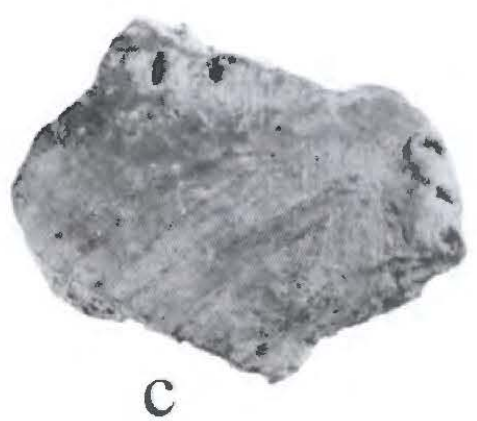

0 5

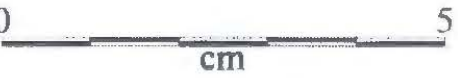

Figure 3. Decorated utility ware sherds: a, tool punctated row below lip of rim sherd; $b$, horizontal brushed and tool punctated row under lip, rim peaked jar; $c$, appliqued-incised body; d, neck banded body; e, tool punctated rim. 
Two of the punctated sherds are rims (direct and everted rim profiles and rounded lips). One has a row of tool punctations on a collar below the lip (see Figure 3a), while the other has rows of tool punctations (see Figure 3e). The third punctated sherd is a body sherd with a row of tool punctations on it.

Most of the utility ware sherds, however, have brushed decorations, either as the sole decoration (36\% of the decorated sherds and $56 \%$ of the utility ware sherds) (Figure 4a, c-e), or in combination with incised (3.6\% of the decorated sherds and $5.6 \%$ of the utility ware sherds) or punctated $(3.6 \%$ of the decorated sherds and $5.6 \%$ of the utility ware sherds) elements (see Figure $3 \mathrm{~b}$ ). The brushed sherds include a rim with horizontal brushing marks, eight body sherds with parallel brushing marks, and another body sherd with overlapping brushing.

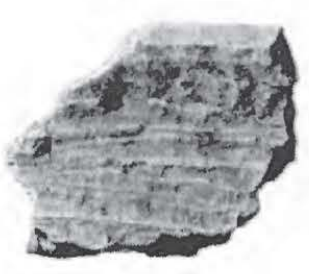

a

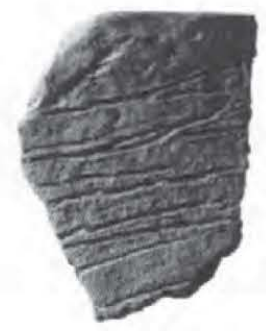

b

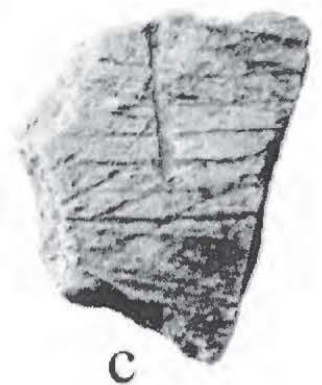

5

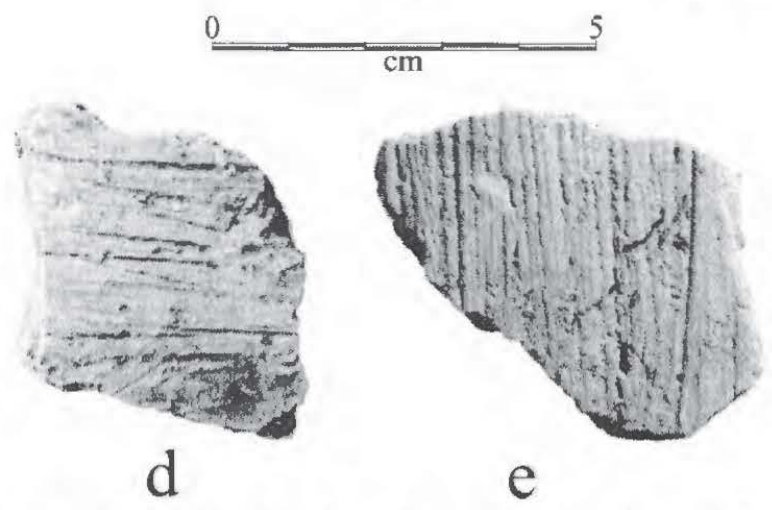

Figure 4. Brushed and incised sherds: a, horizontal brushed rim; b, closely-spaced horizontal incised rim; c-e, parallel brushed body sherds

One rim (everted rim profile and a rounded lip) from a peaked rim jar has horizontal brushing on the rim and a row of tool punctations under the vessel lip (see Figure $3 \mathrm{~b}$ ). A body sherd in the surface collection is decorated with parallel brushed marks and incised lines.

\section{MISCELLANEOUS ARTIFACTS}

Miscellaneous artifacts from midden deposits at the Chasteen site include one mussel shell valve fragment, five animal bones (one burned), 17 pieces of wood charcoal, and 25 pieces of daub. The frequency of daub suggests that there were burned Caddo structures in the area of the surface collection.

\section{CONCLUSIONS}

The Robert L. Turner, Jr. surface collection from a midden area at the Chasteen site is primarily from a Late Caddo Titus phase habitation deposit in the village area. The Titus phase nature of the ceramic assemblage is indicated by the occurrence of sherds from Ripley Engraved carinated bowls, compound bowls, and 
bottles, as well as Harleton Appliqued and La Rue Neck Banded utility ware cooking jars. Brushed vessel sherds are common in the assemblage, with $36 \%$ of the decorated sherds having brushing marks, and this is also consistent with a Titus phase ceramic assemblage. The proportional representation of brushed sherds in this small surface collection suggests that the occupation here took place prior to ca. A.D. 1550, during the early part of the Titus phase.

\section{REFERENCES CITED}

Perttula, T. K.

2012 The Character of Fifteenth- to Seventeenth-Century Caddo Communities in the Big Cypress Creek Basin of Northeast Texas. In The Archaenlogy of the Caddo, edited by T. K. Perttula and C. P. Walker. pp. 363-410. University of Nebraska Press, Lincoln.

Thurmond, J. P.

1990 Archeology of the Cypress Creck Drainage Basin, Northeastern Texas and Northwestern Louisiana. Studies in Archeology 5. Texas Archeological Research Laboratory, The University of Texas at Austin. 